\title{
Genetic homogeneity of Anopheles maculatus in Indonesia and origin of a novel species present in Central Java
}

Triwibowo Ambar Garjito 1,2,3* ${ }^{*}$, Umi Widiastuti ${ }^{1}$, Mujiyono Mujiyono ${ }^{1}$, Mega Tyas Prihatin ${ }^{1}$, Widiarti Widiarti ${ }^{1}$, Riyani Setyaningsih', Siti Alfiah', Barandi Sapta Widartono ${ }^{4}$, Din Syafruddin ${ }^{5}$, Tri Baskoro Tunggul Satoto ${ }^{6}$, Laurent Gavotte ${ }^{7}$, Michael J. Bangs ${ }^{8,9}$, Sylvie Manguin ${ }^{2,3}$ and Roger Frutos $2,10,11$

\begin{abstract}
Background: Anopheles maculatus (s.s.) is an important vector of malaria in Indonesia. Previously it was considered the only member of the Maculatus Group present in Indonesia. A novel species was recently identified in the Kulon Progo District in Central Java. Until recently, few investigations have been conducted looking at An. maculatus genetic diversity in Indonesia, including allopatric island populations.

Methods: Indonesian An. maculatus (s.l.) samples were collected in several locations in Java, Lesser Sunda Island group, Sumatra and in Kulon Progo (Yogyakarta, central Java) where a novel species has been identified. Samples from a 30-year-old colony of the Kulon Progo population were also included in the analysis. Maximum-likelihood analysis established the phylogenies of the ITS2 (nuclear) and cox1 (mitochondrial) markers. Putative times of separation were based on cox 1 genetic distances.

Results: Two species of the Maculatus Group are present in Indonesia. The novel sibling species is more closely related to Anopheles dispar than to An. maculatus (s.s.). Anopheles maculatus (s.s.) samples are homogeneous based on the ITS2 sequences. Indonesian samples and An. dispar belong to the same cox1 maternal lineage and differ from all other known members of the Maculatus Group. Divergence time between the different populations found in Java was estimated using an established cox 1 mutation rate.

Conclusions: A novel species within the Maculatus Group, most closely related to An. dispar, is confirmed present in the Kulon Progo area of Central Java. The divergence of this species from An. maculatus (s.s.) is explained by the stable refugia in the Kulon Progo area during the quaternary period of intense volcanic activity throughout most of Java. This novel species awaits detailed morphological description before applying a formal species name. For the interim, it is proposed that the Kulon Progo population be designated An. maculatus var. menoreh to distinguish it from An. maculatus (s.s.).
\end{abstract}

Keywords: Anopheles maculatus, Maculatus Group, Indonesia, Malaria

*Correspondence: triwibowo@litbang.depkes.go.id

${ }^{1}$ Institute for Vector and Reservoir Control Research and Development, National Institute of Health Research and Development, The Ministry

of Health of Indonesia, Salatiga, Central Java, Indonesia

Full list of author information is available at the end of the article 


\section{Background}

Anopheles maculatus (sensu lato), in the Neocellia Series [1] of the subgenus Cellia, is a widespread species in Asia, ranging from the Indian subcontinent to Southeast Asia and southern China [2-6]. In Indonesia, this species is widely distributed in the western part of the archipelago extending to Weber's Line, a hypothetical biogeographical separation between Sulawesi and the Maluku Islands chain [7]. Anopheles maculatus has been recorded in Sumatra, Java, Kalimantan, Bali, Lesser Sunda Islands including East Timor (Democratic Republic of TimorLeste), and Sulawesi [8].

Prior to the cytogenetic identification of different chromosomal forms, An. maculatus was regarded as a single taxon $[9,10]$. Currently, based on phenotypic characteristics, crossmating experiments, cytogenetic and molecular analyses, the Maculatus Group [11] is divided into two subgroups and nine species $[3,10,12]$. The subgroups are differentiated by distinct morphological characters. The Maculatus Subgroup [13] includes An. maculatus (sensu stricto) Theobald, 1901 and Anopheles dravidicus Christophers, 1924, while the Sawadwongporni Subgroup [13] comprises Anopheles sawadwongporni Rattanarithikul \& Green, 1986 [9], Anopheles notanandai Rattanarithikul \& Green, 1986 [11] and Anopheles rampae Harbach \& Somboon, 2011 [14]. The four other species in the group include Anopheles greeni Rattanarithikul \& Harbach, 1991, Anopheles dispar Rattanarithikul \& Harbach, 1991, Anopheles willmori James, 1903 and Anopheles pseudowillmori Theobald, $1910[12,15,16]$.

The Southeast Asian mainland presents the highest diversity of the Maculatus Group, with seven species present in Thailand $[3,17,18]$. Anopheles greeni and An. dispar appear restricted (endemic) to the Philippines [15]. Five species are found in China excluding An. notanandai and An. rampae [3, 19]. In Vietnam, four species [An. maculatus (s.s.), An. pseudowillmori, An. sawadwongporni and An. rampae] are present [20-22]. Until recently, only An. maculatus (s.l.) [presumed (s.s.)] was reported in Indonesia [8]. A second species has been suspected present in the Kulon Progo District area in Central Java since the late 1990s (MJB, personal communication). This putative, as yet undescribed species was recently reported from material derived from a continuously colonized strain reared [23] over three decades at the Indonesian Ministry of Health Institute for Vector and Reservoir Control Research and Development, a component of the National Institute of Health Research and Development (NIHRD-IVRCRD) and described in this work [24]. Anopheles maculatus has long been considered a major malaria vector in West (peninsular) Malaysia [25], and areas of Sumatra and Java, Indonesia [26-30], predominately in rural, forested areas [31].
Numerous instances of natural malaria plasmodia infections in An. maculatus have been reported in Indonesia [31]. Infection indices have varied from $2.83 \%$ in Kisaran (Sumatra) to 3\% in Central Java, 17\% in Londut (Sumatra) and $11 \%$ in Riau Province (Sumatra) [26, 32]. This species is a major public health concern in the Menoreh Hills region, which includes the Kulon Progo District near the border of Central Java Province and the Special Region of Yogyakarta. It is also reported as a major malaria vector in southern Sumatra (Tenang) [33-36]. Interestingly, although present in Kalimantan, Sulawesi, Bali and the larger islands in the Nusa Tenggara (Lesser Sunda Islands) region, An. maculatus has either not been reported as a malaria vector or is an epidemiologically insignificant species in these areas [37].

We analyzed the diversity and phylogeny of $\mathrm{An}$. maculatus samples collected in different locations and islands in Indonesia. We also analyzed the relationship of the proposed novel species present in Kulon Progo District and reared at NIHRD-IVRCRD with other members of the Maculatus Group to derive its putative origin.

\section{Methods \\ Mosquito collections and identification}

Adult mosquitoes were collected from field settings using standard procedures for human-landing and cattle-landing methods [38] in six provinces of Indonesia between 2012 and 2018. Sampling locations included Cilacap, southern Central Java (samples C1 and C2; October 2011), Belu, West Timor, East Nusa Tenggara (samples NT64 and NT 101; November 2011), Ogan Komering Ulu, South Sumatra (samples S9 and S33; October 2011), Sebatik Island, northern Kalimantan (samples N2 and N44; November 2011), Purbalingga, Central Java (sample P1; September 2011), Kulon Progo, Central Java (samples KP10 and KP72; November 2013) and the NIHRD-IVRCRD laboratory, Salatiga (samples $1 \mathrm{x}, 2 \mathrm{M}$ and 4M; October 2018) (Fig. 1; Table 1). Anopheles maculatus samples were initially identified using morphological criteria [39]. Mosquitoes were sorted and labeled according to locality and date, and stored in $1.5 \mathrm{ml}$ Eppendorf tubes under dry conditions over silica gel until further analysis [13, 39]. Additionally, a laboratory strain of An. maculatus originating from Kulon Progo and under continuous colonization for greater than 30 years at the NIHRD-IVRCRD laboratory in Salatiga, Central Java [23] was compared with more recent field samples from Kulon Progo collected in 2015. To maintain the colony established at IVRCRD Salatiga, wild type material was re-introduced into the laboratory colony in 2003. This re-introduced wild type material was collected in the exact same location as the initial population, i.e. the village of Hargotirto, Kokap subdistrict, Kulon Progo district, Province of 


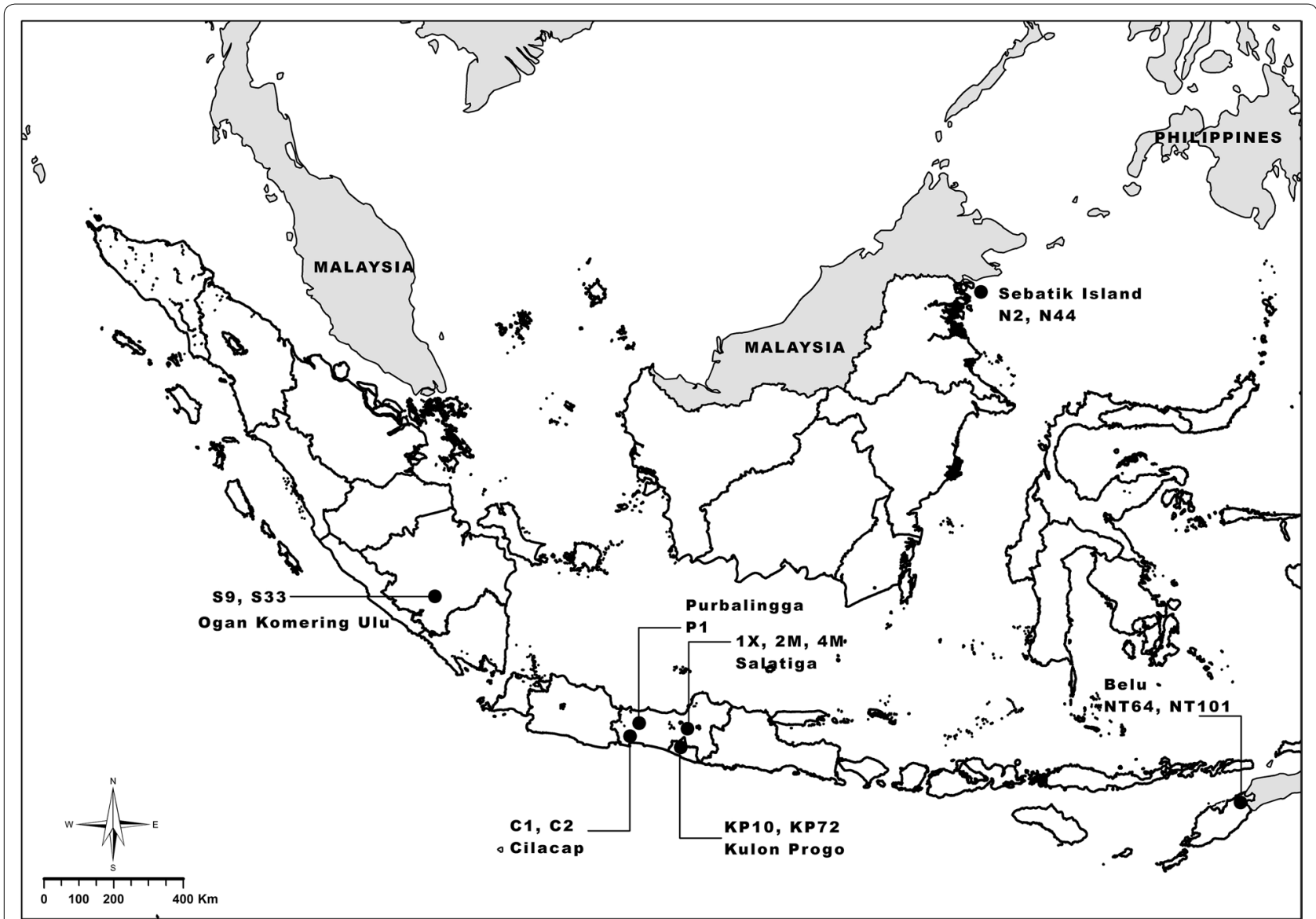

Fig. 1 Map of the sampling sites in Indonesia. Each sampling site is indicated as a black spot. The name of sampling sites and samples are indicated. The source of geographical data layers is the Indonesia Geospatial Information Agency who granted the permission and rights to publish this map

Yogyakarta. Representative field-collected specimens are deposited in the Systematics and Reference Laboratory, IVRCRD, Salatiga.

\section{DNA extraction, amplification and sequencing}

DNA was extracted from the legs of each mosquito using a DNeasy ${ }^{\circledR}$ Blood \& Tissue Kit (Qiagen, Hilden, Germany) with modification based on the manufacturer's protocol. The amplification of ITS2 was performed with primers ITS2a (5'-TGT GAA CTG CAG GAC ACA T-3') and ITS2b (5'-TAT GCT TAA ATT CAG GGG GT-3') [39]. cox1 was amplified using the primers CI-N-2087 (5'-AAT TTC GGT CAG TTA ATA ATA TAG- $\left.3^{\prime}\right)$ and TY-J-1460 (5'-TAC AAT TTA TCG CCT AAA CTT CAG CC-3'). PCR reactions were carried out using GoTaq ${ }^{\circledR}$ Green Master Mix (Promega, Madison, WI, USA). PCR thermocycling conditions for ITS2 were as follows: $94{ }^{\circ} \mathrm{C}$ for $10 \mathrm{~min}$; followed by 40 cycles of denaturation at $94{ }^{\circ} \mathrm{C}$ for $1 \mathrm{~min}$, annealing at $56{ }^{\circ} \mathrm{C}$ for $45 \mathrm{~s}$ and elongation at $72{ }^{\circ} \mathrm{C}$ for $1 \mathrm{~min}$; followed by a final extention step at $72{ }^{\circ} \mathrm{C}$ for $10 \mathrm{~min}$. For amplification of the cox 1 gene, the following conditions were used: initial denaturation at $94{ }^{\circ} \mathrm{C}$ for $1 \mathrm{~min}$ followed by five cycles of $94^{\circ} \mathrm{C}$ for $30 \mathrm{~s}, 45^{\circ} \mathrm{C}$ for $40 \mathrm{~s}$ and $72{ }^{\circ} \mathrm{C}$ for $1 \mathrm{~min}$; this was then followed by 35 cycles of $94{ }^{\circ} \mathrm{C}$ for $30 \mathrm{~s}, 55^{\circ} \mathrm{C}$ for $40 \mathrm{~s}$ and $72{ }^{\circ} \mathrm{C}$ for $1 \mathrm{~min}$, and by a final extention step at $72{ }^{\circ} \mathrm{C}$ for $10 \mathrm{~min}$ [40]. The amplified PCR products were separated by $1.5 \%$ agarose gel electrophoresis and vizualized by $\mathrm{SYBR}^{\circledR}$ safe DNA gel stain (Invitrogen, Carlsbad, CA, USA). A 100bp DNA ladder was used for calculating the size of the PCR products. Amplification products were purified using Applied Biosystems ExoSAP-IT ${ }^{\mathrm{TM}}$ (Thermo Fisher Scientific, Vilnius, Lithuania). Cycle sequencing was performed using the primers listed above and an Applied Biosystems BigDye ${ }^{\mathrm{TM}}$ Terminator v.3.1 Cycle Sequencing Kit (Life Technologies Cooperation, Austin, TX, USA). To remove unicorporated BigDye ${ }^{\circledR}$ terminators and salts, cycle sequencing products were purified using a BigDye ${ }^{\circledR}$ Xterminator Purification Kit (Life technologies, Bedford, MA, USA). Sequence data were obtained using a DNA sequencer (Applied 
Table 1 Sampling localities and specimens of Anopheles mosquitoes

\begin{tabular}{|c|c|c|c|c|c|c|}
\hline Sample code & Location & Ecology & Altitude range $(\mathrm{m})$ & $\begin{array}{l}\text { Role as } \\
\text { malaria } \\
\text { vector }\end{array}$ & GenBank ID (ITS2) & GenBank ID (cox 1$)$ \\
\hline P1 & Purbalingga, Java & Wet rice field, plantation & $250-329$ & Yes & MK656100 & MK683475 \\
\hline $\mathrm{C} 1$ & Cilacap, Java & $\begin{array}{l}\text { Secondary forest, plantation, } \\
\text { wet rice field }\end{array}$ & $300-348$ & No & MK656095 & MK683467 \\
\hline C2 & Cilacap, Java & $\begin{array}{l}\text { Secondary forest, plantation, } \\
\text { wet rice field }\end{array}$ & $300-348$ & No & MK656096 & MK683468 \\
\hline KP10 & Kulon Progo Java & Secondary forest, wet rice field & $300-1000$ & Yes & MK659792 & MK683471 \\
\hline KP72 & Kulon Progo Java & Secondary forest, wet rice field & $300-1000$ & Yes & MK659780 & MK683472 \\
\hline $1 \times$ & $\begin{array}{l}\text { Insectary laboratory IVRCRD } \\
\text { Salatiga (origin Kulon Progo) }\end{array}$ & Laboratory conditions & 700 & Yes & MK659773 & MK683464 \\
\hline $2 \mathrm{M}$ & $\begin{array}{l}\text { Insectary laboratory IVRCRD } \\
\text { Salatiga (origin Kulon Progo) }\end{array}$ & Laboratory conditions & 700 & Yes & MK675654 & MK683465 \\
\hline $4 \mathrm{M}$ & $\begin{array}{l}\text { Insectary laboratory IVRCRD } \\
\text { Salatiga (origin Kulon Progo) }\end{array}$ & Laboratory conditions & 700 & Yes & MK675653 & MK683466 \\
\hline NT64 & Belu, East Nusa Tenggara & Secondary forest, wet rice field & $150-215$ & Yes & MK659796 & MK683473 \\
\hline NT101 & Belu, East Nusa Tenggara & Secondary forest, wet rice field & $150-215$ & Yes & MK659794 & MK683474 \\
\hline S9 & Ogan Komering Ulu Sumatra & Coffee and rubber plantations & $800-892$ & Yes & MK659795 & MK683476 \\
\hline S33 & Ogan Komering Ulu Sumatra & Coffee and rubber plantations & $800-892$ & Yes & MK659793 & MK683477 \\
\hline N2 & Sebatik Island Kalimantan & $\begin{array}{l}\text { Coconut, palm oil, coffee and } \\
\text { cacao plantations }\end{array}$ & $150-218$ & Yes & MK659798 & MK683469 \\
\hline N44 & Sebatik Island Kalimantan & $\begin{array}{l}\text { Coconut, palm oil, coffee and } \\
\text { cacao plantations }\end{array}$ & $150-218$ & Yes & MK659797 & MK683470 \\
\hline
\end{tabular}

Biosystems ${ }^{\circledR} 3500$ Genetic Analyzer) and analyzed using the Sequencing Analysis 6 program (Applied Biosystems).

\section{Sequence analysis}

Sequences were edited using Sequencing Analysis v.5.2 (Applied Biosystems). Sequences were aligned with MUSCLE using SeaView v.4.7 [41] and Mega X [42]. Phylogenetic trees were constructed with the maximum likelihood (ML) method and the Kimura-2 (K80) evolutionary model in Mega X. To assess the ML tree reliability, bootstraps were tested with 1000 replicates. To estimate the evolutionary divergence between sequences, genetic distances were analyzed by pairwise distance (p-distance) methods [43] in Mega X. Divergence time was calculated based on previously reported estimates giving 1 million years (Myr) for 2.3\% difference [44, 45]. Sequences are deposited in GenBank under the following accession numbers: ITS2: N2 (MK659798), N44 (MK659797), S9 (MK659795), S33 (MK659793), NT64 (MK659796), NT101 (MK659794), KP10 (MK659792), KP72 (MK659780), 1x (MK659773), 2M (МK675654), 4M (MK675653), P1 (MK656100), C1 (MK656095) and C2 (MK656096); cox1: N2 (MK683469), N44 (MK683470), S9 (MK683476), S33 (MK683477), NT64 (MK683473), NT101 (MK683474), KP10 (MK683471), KP72 (MK683472), 1x (MK683464), 2M (MK683465),
4M (MK683466), P1 (MK683475), C1 (MK683467) and C2 (MK683468).

\section{Results}

ITS2 diversity and phylogeny of Anopheles maculatus

The comparative analysis of the ITS2 sequences of all An. maculatus samples and of available reference sequences from other members of the Maculatus Group and select other Anopheles species present in Indonesia indicates that two populations of $A n$. maculatus are present in Indonesia. Samples of An. maculatus coming from Purbalingga (P1), Cilacap (C1, C2), Belu (NT64, NT101), Sebatik Island (N2, N44) and Ogan Komering Ulu (S9, S33) displayed 100\% genetic similarity and were also $100 \%$ identical to $A n$. maculatus sequences from the mainland Asian continent (Fig. 2, Additional file 1: Table S1). The GenBank An. maculatus sequences used as reference corresponded to mosquitoes isolated in India (JQ446438), Thailand (DQ518615), Vietnam (AY803351), Malaysia (DQ518619), Cambodia (DQ518618) and China (DQ518616). For the nuclear ribosomal ITS2 sequence, the similarity between all An. maculatus reference sequences and sequences from samples P1, C1, C2, NT64, NT101, N2, N44, S9 and S33 indicated a high conservation and genetic homogeneity regardless of distribution and geographical distance (Fig. 2). There was also no difference between samples from the continental 


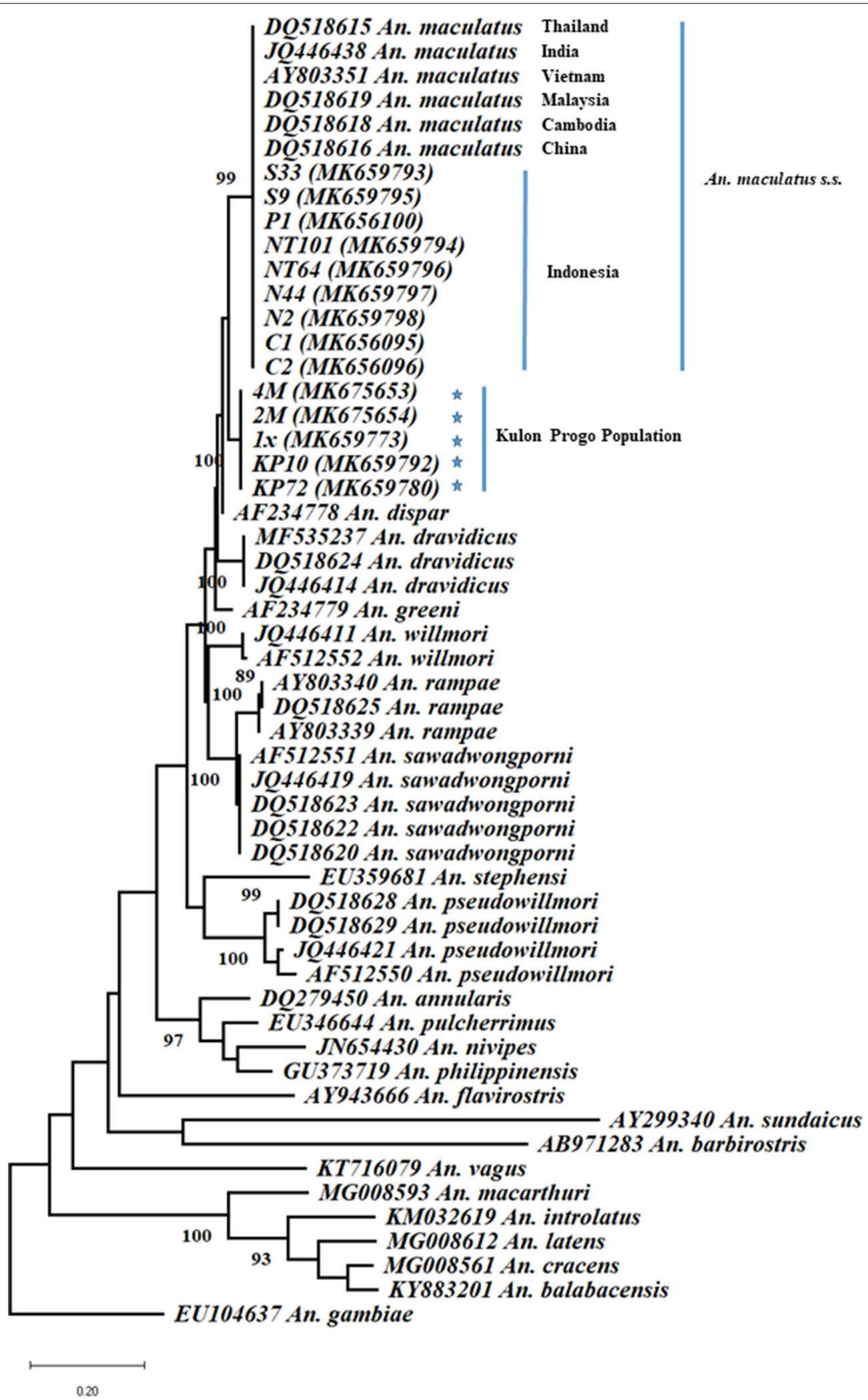

Fig. 2 Phylogenetic analysis of the ITS2 sequences. Kulon Progo samples are identified with blue stars. The phylogenetic tree was constructed using the maximum likelihood (ML) method and the Kimura-2 (K80) evolutionary model in Mega X. To assess the ML tree reliability, bootstraps were tested at 1000 replicates 
Asian land mass and island groups. Conversely, the samples KP10, KP72, 1x, 2M and 4M isolated from Kulon Progo did not cluster with the continental An. maculatus sequences producing a separate, genetically distinct and homogeneous group more closely related to An. dispar. The sequences $1 \mathrm{x}, 2 \mathrm{M}$ and $4 \mathrm{M}$, which correspond to a laboratory strain of An. maculatus collected decades ago in Kulon Progo, were identical to those samples collected for this work, i.e. KP10 and KP72, indicating strong genetic stability after years of continuous colonization.

This phylogenetic analysis indicates that although separated into two different genetic aggregates (groups), collectively the Indonesian samples belong to the Maculatus Group. With respect to genetic distances, the samples displayed two ranges of distances depending on the group considered (Additional file 1: Table S1). The Indonesian An. maculatus group, i.e. samples P1, C1, C2, NT64, NT101, S9, S33, N2 and N44, showed no genetic distance with the continental An. maculatus reference sequences. The ITS2 sequence appears entirely conserved. The genetic distance within the Maculatus Group ranged between 2.7-20.8\%, while the genetic distance of the An. maculatus sequences from other group members ranged between 5-16.5\% (Additional file 1: Table S1). The Kulon Progo samples (KP10, KP72, 1x, 2M and 4M) displayed no (0\%) internal group distance and a 5.5-5.8\% distance with the other An. maculatus sequences. Comparison with other members, the Kulon Progo sequences displayed distances of $3 \%, 6.5 \%, 7.7-8,8 \%, 10.4-10.9 \%$, 15.5-17\% and $10.9 \%$ with An. dispar, An. greeni, An. dravidicus, An. sawadwongporni, An. willmori, An. pseudowillmori and An. rampae, respectively (Additional file 1: Table S1). The alignment of the Kulon Progo ITS2 sequences with $A n$. maculatus (s.s.) from Indonesia, $A n$. maculatus (s.s.) from mainland Asia, and An. dispar is provided in Additional file 2: Figure S1.

\section{cox 1 diversity and phylogeny of Anopheles maculatus}

The comparative analysis of the mitochondrial cox 1 sequences, indicative of the maternal lineage, showed that all the samples and reference sequences belonged to four genetically distinct and separated lineages, Lineage 1 being separated into two sublineages (Fig. 3a). Lineage 4 comprised only Anopheles sinensis (subgenus Anopheles, Hyrcanus Group) and was therefore used as outgroup for the rooted tree (Fig. 3b). Lineage 1a comprised Anopheles stephensi, Anopheles flavirostris, An. dispar (a Maculatus Group member), all the Indonesian samples including the Kulon Progo population, An. gambiae and Anopheles barbirostris (Clade I); while Lineage $1 \mathrm{~b}$ included three out four species of the Leucosphyrus Complex, along with Anopheles macarthuri, a member of the Riparis

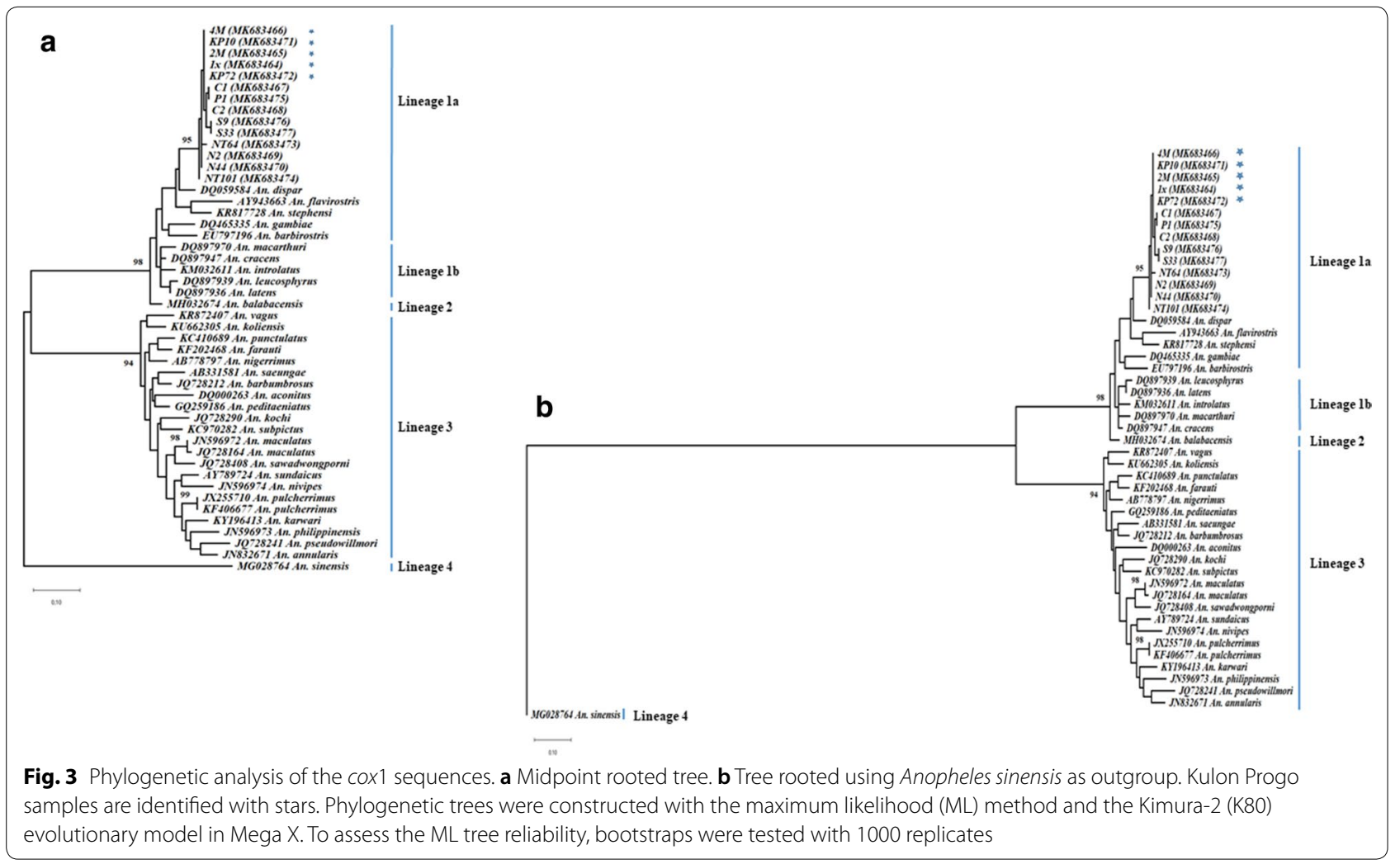


Subgroup, and Anopheles cracens, a member of the Dirus Complex, all five belonging to the Leucosphyrus Group [14]. Lineage 2 comprised only An. balabacensis, the fourth species of the Leucosphyrus Complex. Lineage 3 comprised all of the An. maculatus reference samples and members of the Maculatus Group available in GenBank, excluding An. dispar and the Indonesian An. maculatus samples. Lineage 3 and Lineage 4 branched directly on the root; whereas, Lineage $1 \mathrm{a}$ and Lineage $1 \mathrm{~b}$ were further separated by a bootstrap of 99. The Indonesian $A n$. maculatus sequences within Lineage 1a grouping displayed some internal genetic variability. All Kulon Progo samples examined were identical, while genetic distances of up to $2.6 \%$ were observed with An. maculatus (s.s.) from Indonesian (Additional file 3: Table S2). With respect to the other members of Lineage 1a, the closest species was $A n$. dispar with a percentage of divergence ranging between $7.8-8.4 \%$ depending on the sample. The divergence of the Indonesian samples with An. flavirostris (Minimus Subgroup) ranged between 12.2-13.5\%, while An. stephensi (Neocellia Series) ranged between 10.4-12.2\% (Additional file 3: Table S2). The alignment of the cox 1 sequences of the Kulon Progo samples, An. maculatus (s.s.) from Indonesia, An. maculatus (s.s.) from mainland Asia, and An. dispar is provided in Additional file 4: Figure S2.

\section{Time of divergence}

The time of divergence was calculated based on previously reported estimates of the variation of the cox 1 gene in the genus Anopheles where $2.3 \%$ of divergence is estimated to correspond to 1 million years (Myrs) [42, 43]. The estimated time of divergence of An. maculatus (s.s.) from the Kulon Progo population and from $A n$. dispar was estimated at between 26-26.2 Myrs, and between 30.2-30.9 Myrs, respectively, which corresponds to the Oligocene Epoch. The divergence of the Kulon Progo population from the other members of the Kulon Progo maternal lineage, i.e. An. dispar, An. flavirostris and An. stephensi, is dated 3.4 (Pliocene Epoch), 5.3 (Miocene Epoch) and 5.04 Myrs (Pliocene), respectively. The other Indonesian $A n$. maculatus sequences displayed the same separation time with An. dispar as the Kulon Progo population with the exception of NT101 (Belu, East Nusa Tenggara), C1 (Cilacap, Central Java) and P1 (Purbalingga, Central Java), indicating separation around 3.13 and 3.65 Myrs ago (Pliocene), respectively. The separation of the Kulon Progo population from the other Indonesian An. maculatus samples was dated 0.65 (NT64, S9, S33), 0.43 (NT101, C1, P1) and 0.22 Myrs (C2, N2, N44), all corresponding to the latter part of the Pleistocene Epoch.

\section{Discussion}

Anopheles maculatus (s.s.) was previously believed to be the only member of the Maculatus Group present in Indonesia, a species regarded as an important vector of malaria in certain localities [6]. This Asian group is a diverse assemblage with at least nine described species, five of which fall into two subgroups [3, 10, 12]. Investigating the diversity of $A n$. maculatus in Indonesia was therefore a prerequisite for a better understanding of the distribution, bionomics and variations in vector capacity over its wide geographical range. The investigation reported herein provides several conclusions. First, there is definitive evidence of at least two species within the Maculatus Group in Indonesia, confirming a recent report by Ali et al. [24], which raises the number of species to ten (none of which are nominal taxon) within the Maculatus Group. Secondly, An. maculatus (s.s.) appears genetically homogeneous throughout its geographical range in Asia. Thirdly, members of the group in Indonesia differ by maternal origin from all other members, including An. maculatus (s.s.) from mainland Asia, with the lone exception of $A n$. dispar.

The Kulon Progo population has been suspected as a distinct species within the Maculatus Group based on unpublished work spanning several decades (MJB, personal comm). This population was recently proposed as a different species based on selected morphological characters and genetic (ITS2 and cox2) sequences [24]. The ITS2 phylogenetic analysis in the present study confirmed that the Kulon Progo population and all other known $A n$. maculatus sequences analyzed in Indonesia are members of the Maculatus Group, yet they also comprise genetically distinct groups. ITS2 is not considered a good intraspecific marker due to its low evolution rate and high conservation; however, it is a good marker at the species level showing clear discrimination indicative of species separation [46-50]. The phylogenetic distance between the ITS2 sequences of the Kulon Progo population and other An. maculatus sample sequences both Indonesia and mainland Asia included in the analysis ranged between $5.5-5.8 \%$. This is greater than the ITS2 distances displayed by other groups of closely related Anopheles species. For example, two sibling species in the Anopheles farauti complex (an assemblage of 8 species) differ by only $4.0 \%$ [51], while $A n$. greeni and An. dispar (Maculatus Group) also differ by $4.0 \%$ [52]. In Africa, five species within the An. gambiae complex show intraspecific differences ranging between $0.4-1.6 \%$ [53], while two members of the $A n$. dirus complex, An. dirus (s.s.) (formerly species A) and An. baimaii (species D), display $5.4 \%$ genetic distance [54]. The Kulon Progo population was shown to be morphologically distinct from $A n$. maculatus (s.s.) while cross-mating experiments generated 
partially sterile hybrids [24]. The combined evidence confirms that the Kulon Progo population is a distinct species and one that likely extends throughout the greater Menoreh Hill region in central Java. Until a formal morphological description can be made, it is hereby proposed that the Kulon Progo population be designated an infrasubspecific entity, An. maculatus var. menoreh, in reference to its region of origin and to distinguish it from An. maculatus (s.s.).

The two Indonesian members of the Maculatus Group and $A n$. dispar belong to the same mitochondrial lineage and differ from that of all other known members of the group outside Indonesia. Collectively, these data demonstrate the occurrence in Indonesia of an introgression of the An. maculatus (s.s.) chromosomal genome from continental to insular populations. A similar phenomenon of introgression has been demonstrated for Anopheles sundaicus complex in Southeast Asia [44]. Introgression is a key adaptive mechanism of Anopheles mosquitoes to exist in various environments $[44,55]$, and well described in the Anopheles gambiae complex [56, 57].

The Pleistocene Epoch (2.58 Myrs to 11,700 years ago) is believed to have played a key role in the distribution of Anopheles mosquitoes in Southeast Asia [46, 58-60]. The period was characterized by a series of glaciation and inter-glaciation periods, which generated dramatic climatic changes and large variations in sea level $[61,62]$. During glaciation periods, islands west of the Wallace's Line were interconnected on the same land mass known as the Sunda Shelf [63-65]; whereas, during inter-glaciation events the rainforest environments expanded, thus providing more favorable habitats for Anopheles mosquitoes while island landmasses remained isolated. Sulawesi, the eastern Lesser Sunda and Maluku island chains, and western New Guinea Island were isolated and separated by sea from the western half of the Indonesian archipelago, while the Philippines followed a different biogeographical evolution. Palawan Island (western Philippines) was then connected to the Sunda Shelf but later separated and collided with the mobile belt of the Philippine archipelago. This geological history induced by shifts in climate is considered to have greatly influenced the current structural diversity of Anopheles populations in Southeast Asia and the evolution of present-day species complexes through successive genetic expansions and bottlenecks [66].

Based on the molecular evidence, the Kulon Progo population appears more closely related to An. dispar, a species that appears confined to the northern Philippines. The most parsimonious way to explain this geographical discrepancy is that their common ancestors gradually moved from continental Asia to the current island territories during the Oligocene, which corresponds to the calculated separation of the Kulon Progo lineage from the continental An. maculatus (s.s.) lineage (between 23 and 26.4 Myrs). A movement of An. maculatus from the continent appears to have occurred before 3.4 Myrs ago (between the late Oligocene and early Pliocene epochs), the calculated time of separation between An. dispar and the Kulon Progo population. This event led to introgression of the An. maculatus chromosomal genome into at least a portion of the maternal lineage identified as Lineage 1. During the Pliocene (3.4 Myrs ago), the ancestor of An. dispar was separated from the main introgressed population, likely the result of the tectonic shift of Palawan Island towards the current Philippine archipelago. During the Pleistocene, increased volcanism occurred in central and eastern Java but the Kulon Progo area was naturally spared from the surrounding destruction and served as a relic forest refuge [67]. This isolation event occurred between 0.22 and 0.65 Myrs, which corresponds to the calculated separation time between the Kulon Progo population and the other Indonesian archipelagic An. maculatus populations. During the late Pleistocene period (200,000 to 11,700 years ago), at least one other species invasion and introgression by continental An. maculatus appears to have occurred which generated the current Indonesian populations of An. maculatus (s.s.). This timescale is in agreement with that calculated for the movements of populations and introgression detected in An. sundaicus in Southeast Asia [44, 45].

\section{Conclusions}

Anopheles maculatus, along with Anopheles balabacensis, is the main malaria vector species occuring in the Kulon Progo area and the greater Menoreh region [33-37, 6871]. The evidence presented here confirms that the Kulon Progo population is a distinct species and one that likely extends throughout the greater Menoreh Hill region in central Java. There are now two recognized members of the Maculatus Group present in Indonesia. However, a detailed morphological description of this novel species is required to establish a new nominal taxon. To distinguish it from An. maculatus (s.s.), in the interim it is hereby proposed an infrasubspecific entity ('variety'), $A n$. maculatus var. menoreh.

\section{Additional files}

Additional file 1: Table S1. Pairwise genetic distance of ITS2 sequences Genetic distances were calculated with the Kimura 2 parameters using Mega $X$.

Additional file 2: Figure S1. Alignment of ITS2 sequences. Alignment performed using Seaview v.4.7 with MUSCLE program for multialignment. 
Additional file 3: Table S2. Pairwise genetic distance of cox1 sequences Genetic distances were calculated with the Kimura 2 parameters using Mega X.

Additional file 4: Figure S2. Alignment of cox1 gene sequences. Alignment performed using Seaview v.4.7 with MUSCLE program for multialignment.

\section{Abbreviations}

ITS2: internal transcribed spacer 2; cox1: cytochrome oxidase subunit I; ML: maximum likelihood.

\section{Acknowledgements}

This paper is dedicated to the late Dr Umi Widiastuti, Professor Damar Tri Boewono, Professor Supratman Sukowati and Retno Ambar Yuniarti who provided years of valuable contributions to mosquito studies in Indonesia. The authors also gratefully acknowledge Lasmiati, Heru Priyanto, Kusno Barudin, Warido, Sapto Prihasto Siswoko, Valentinus Widiratno, Rima Tunjungsari Dyah Ayuningtyas, Fahmay Dwi Ayuningrum, Sidiq Setyo Nugroho, Sugiarto and other members of the IVRCRD laboratory for their teamwork in support of fieldwork in collecting and rearing the mosquitoes used in the study. We also acknowledge the kind support from Jerry Cahyandaru for his help.

\section{Authors' contributions}

TAG, UW, MM and MTP conceived and designed the field and laboratory experiments. TAG, UW, DS and MTP designed the molecular experiments, TAG, UW, MM, MTP, WW, RS, SA and TBTS performed the experiments. TAG, $L G$ and RF analyzed the data. BSW prepared the maps. TAG and RF wrote the manuscript. SM, LG and MJB provided a critique of and significant revisions to the manuscript. All authors read and approved the final manuscript.

\section{Funding}

The research was supported by the Institute for Vector and Reservoir Control Research and Development, National Institute of Health Research and Development, Ministry of Health Indonesia. MJB was supported bylnternational SOS. SM, LG and RF were supported by the Université de Montpellier, IRD, ISEM and CIRAD, Montpellier, France.

\section{Availability of data and materials}

Data supporting the conclusions of this article are included within the article and its additional files. Raw data are available from the corresponding author upon reasonable request. ITS2 sequences are deposited under accession numbers: N2 (MK659798), N44 (MK659797), S9 (MK659795), S33 (MK659793), NT64 (MK659796), NT101 (MK659794), KP10 (MK659792), KP72 (MK659780), 1x (MK659773), 2M (MK675654), 4M (MK675653), P1 (MK656100), C1 (MK656095) and C2 (MK656096). cox1 sequences are deposited under accession numbers: N2 (MK683469), N44 (MK683470), S9 (MK683476), S33 (MK683477), NT64 (MK683473), NT101 (MK683474), KP10 (MK683471), KP72 (MK683472), 1x (MK683464), 2M (MK683465), 4M (MK683466), P1 (MK683475), C1 (MK683467) and C2 (MK683468).

\section{Ethics approval and consent to participate}

This study involved the use of humans to collect adult mosquitoes in natural settings. Formal approval to conduct these activities was provided by the Ethical Commission Board of the NIHRD, Ministry of Health, Indonesia (no. KE.01.03/EC/077/2011, March 8, 2011).

\section{Consent for publication}

Not applicable.

\section{Competing interests}

The authors declare that they have no competing interests.

\section{Author details}

${ }^{1}$ Institute for Vector and Reservoir Control Research and Development, National Institute of Health Research and Development, The Ministry of Health of Indonesia, Salatiga, Central Java, Indonesia. ${ }^{2}$ University of Montpellier, Montpellier, France. ${ }^{3}$ HydroSciences Montpellier (UMR-HSM), Institut de Recherche pour le Développement (IRD France), CNRS, Montpellier, France.

${ }^{4}$ Department of Geographical Information System, Faculty of Geography,
Gadjah Mada University, Yogyakarta, Indonesia. ${ }^{5}$ Eijkman Institute for Molecular Biology, Jakarta, Indonesia. ${ }^{6}$ Department of Parasitology, Faculty of Medicine, Public Health and Nursing, Gadjah Mada University, Yogyakarta, Indonesia. ${ }^{7}$ ISEM, University of Montpellier, Montpellier, France. ${ }^{8}$ Public Health \& Malaria Control, International SOS/PT. Freeport Indonesia, Kuala Kencana, Indonesia. ${ }^{9}$ Department of Entomology, Faculty of Agriculture, Kasetsart University, Bangkok, Thailand. ${ }^{10} \mathrm{IES}$, University of Montpellier, CNRS, Montpellier, France. ${ }^{11}$ Cirad, UMR 17, Intertryp, Montpellier, France.

Received: 5 April 2019 Accepted: 5 July 2019

Published online: 15 July 2019

\section{References}

1. Christophers S. Provisional list and reference catalogue of the Anophelini. Indian Med Res Mem. 1924;3:1-105.

2. Rongnoparut P, Sirichotpakorn N, Rattanarithikul R, Yaicharoen S, Linthicum KJ. Estimates of gene flow among Anopheles maculatus populations in Thailand using microsatellite analysis. Am J Trop Med Hyg. 1999:60:508-15.

3. Ma Y, Li S, Xu J. Molecular identification and phylogeny of the Maculatus group of Anopheles mosquitoes (Diptera: Culicidae) based on nuclear and mitochondrial DNA sequences. Acta Trop. 2006;99:272-80.

4. Green CA, Rattanarithikul R, Pongparit S, Sawadwongporn P, Baimai V. A newly-recognized vector of human malarial parasites in the oriental region, Anopheles (Cellia) pseudowillmori (Theobald, 1910). Trans R Soc Trop Med Hyg. 1991;85:35-6.

5. Sinka ME, Bangs MJ, Manguin S, Chareonviriyaphap T, Patil AP, Temperley $\mathrm{WH}$, et al. The dominant Anopheles vectors of human malaria in the AsiaPacific region: occurrence data, distribution maps and bionomic précis. Parasit Vectors. 2011:4:89.

6. Manguin S, Garros C, Dusfour I, Harbach RE, Coosemans M. Bionomics, taxonomy, and distribution of the major malaria vector taxa of Anopheles subgenus Cellia in Southeast Asia: an updated review. Infect Genet Evol. 2008:8:489-503.

7. Darlington PJ Jr. Zoogeography: the geographical distribution of animals. New York: Wiley; 1957.

8. O'Connor CT, Sopa T. A checklist of the mosquitoes of Indonesia. 1981. http://oai.dtic.mil/oai/oai?verb=getRecord\&metadataPrefix=html\&ident ifier=ADA117969. Accessed 16 Oct 2017.

9. Green CA, Baimai V, Harrison BA, Andre RG. Cytogenetic evidence for a complex of species within the taxon Anopheles maculatus (Diptera: Culicidae). Biol J Linn Soc. 1985;24:321-8.

10. Baimai V, Kijchalao U, Rattanarithikul R, Green CA. Metaphase karyotypes of Anopheles of Thailand and Southeast Asia. II. Maculatus group, Neocellia series, subgenus Cellia. Mosq Syst. 1993;25:116-23.

11. Rattanarithikul R, Green C. Formal recognition of the species of the Anopheles maculatus group (Diptera: Culicidae) occurring in Thailand, including the descriptions of two new species and a preliminary key to females. Mosq Syst. 1986;18:246-78.

12. Harbach RE. The phylogeny and classification of Anopheles. In: Manguin S, editor. Anopheles mosquitoes: new insights into malaria vectors. London: IntechOpen; 2013. p. 3-55.

13. Rattanarithikul R, Harrison B, Harbach RE, Panthusiri P, Coleman R. Illustrated keys to the mosquitoes of Thailand. IV. Anopheles. Southeast Asian J Trop Med Public Health. 2006;37(Suppl. 2):1-128.

14. Harbach RE. Genus Anopheles Meigen. Mosquito taxonomic inventory. 2019. http://www.mosquito-taxonomic-inventory.info/genus-anophelesmeigen-1818. Accessed 20 May 2019.

15. Morgan K, O'Loughlin SM, Mun-Yik F, Linton Y-M, Somboon P, Min S, et al. Molecular phylogenetics and biogeography of the Neocellia series of Anopheles mosquitoes in the Oriental Region. Mol Phylogenet Evol. 2009;52:588-601.

16. Tainchum K, Kongmee M, Manguin S, Bangs MJ, Chareonviriyaphap T. Anopheles species diversity and distribution of the malaria vectors of Thailand. Trends Parasitol. 2015;31:109-19.

17. Rattanarithikul R, Harbach RE. Anopheles maculatus (Diptera: Culicidae) from the type locality of Hong Kong and two new species of the Maculatus complex from the Philippines. Mosq Syst. 1990;22:160-83. 
18. Somboon $\mathrm{P}$, Thongwat $\mathrm{D}$, Harbach RE. Anopheles (Cellia) rampae $\mathrm{n}$. sp. alias chromosomal form $\mathrm{K}$ of the oriental Maculatus group (Diptera: Culicidae) in Southeast Asia. Zootaxa. 2011;55:47-55.

19. Ji SH, Lu BL. A note on the Anopheles maculatus group of China. Acta Zootax Sin. 1991;16:224-7.

20. Walton C, Somboon P, O'Loughlin SM, Zhang S, Harbach RE, Linton YM, et al. Genetic diversity and molecular identification of mosquito species in the Anopheles maculatus group using the ITS2 region of rDNA. Infect Genet Evol. 2007:7:93-102.

21. Do Manh C, Beebe NW, Le Quang T, Lein CT, Van Nguyen D, Xuan TN, et al. Vectors and malaria transmission in deforested, rural communities in north-central Vietnam. Malar J. 2010;9:259.

22. Ngo CT, Dubois G, Sinou V, Parzy D, Le HQ, Harbach RE, Manguin S. Diversity of Anopheles mosquitoes in Binh Phuoc and Dak Nong Provinces of Vietnam and their relation to disease. Parasit Vectors. 2014;7:316.

23. Bangs MJ, Soelarto T, Wicaksana BP, Buwono DT. Colonization of Anopheles maculatus Theobald from Central Java, Indonesia. J Am Mosq Control Assoc. 2002;18:359-63.

24. Ali RSM, Wahid I, Saeung A, Wannasan A, Harbach RE, Somboon P. Genetic and morphological evidence for a new species of the Maculatus group of Anopheles subgenus Cellia (Diptera: Culicidae) in Java, Indonesia. Parasit Vectors. 2019;12:107.

25. Watson M. Mosquito reduction and the consequent eradication of malaria. Trans R Soc Trop Med Hyg. 1913;7:59-82.

26. Doorenbos WB. Some experiences in the field of malaria. Vol. I-III. Med J Dutch East Indies. 1931;71(I,II,II):1229-48, 1379-94, 1458-7148.

27. Sundararaman S, Soeroto RM, Siran M. Vectors of malaria in mid-Java. Indian J Malariol. 1957;1 1:321-38.

28. Walch EW, Soesilo R. Malaria control in the Netherlands Indies. Ned Public Health Commun. 1935;24:86-94.

29. Overbeek JG, Stoker WJ. Malaria in the Dutch East Indies and its control. Ned J Public Health Commun. 1938;28:183-205.

30. Soemarlan, Gandahusada S. The fight against malaria: a historical review and future outlook. Jakarta: NIHRD, Minist of Health Indonesia Press; 1990. p. 63.

31. Takken W, Snellen WB, Verhave JP, Knols BGJ, Atmosoedjono S. Environmental measures for malaria control in Indonesia - an historical review on species sanitation. Wageningen: Wageningen Agricultural University; 1991. p. 90-7.

32. Swellengrebel NH, Rodenwaldt E. The Anophelines of Dutch East Indies. 3rd ed. Jena: Gustav Fischer; 1932. p. 242.

33. Wigati RA, Mardiana, Arianti Y, Mujiyono. Incrimination of An vagus Donitz, 1902 mosquito (Diptera: Culicidae) as a malaria vector in Kokap subdistrict, Kulon Progo district, Yogyakarta. Ind J Health Sci. 2006;19:503-16.

34. Barcus MJ, Laihad F, Sururi M, Sismadi P, Marwoto H, Bangs MJ, et al. Epidemic malaria in the Menoreh Hills of Central Java. Am J Trop Med Hyg. 2002;66:287-92.

35. Lestari EW, Sukowati S, Arianti Y, Efriwati E, Shinta S, Wigati RA. Bionomic of malaria vector Anopheles maculatus and An. balabacensis in Menoreh hills, Purworejo, Central Java. Jakarta: NIHRD, Ministry of Health Indonesia; 2000. p. 26.

36. Bangs MJ, Rusmiarto S. Malaria vector incrimination in Indonesia using CSP-ELISA from 1986 to 2007. Jakarta: US Naval Medical Research Unit 2 (NAMRU-2); 2007. Unpublished report.

37. Elyazar IRF, Sinka ME, Gething PW, Tarmidzi SN, Surya A, Kusriastuti R, et al. The distribution and bionomics of Anopheles malaria vector mosquitoes in Indonesia. Adv Parasitol. 2013:83:173-266.

38. WHO. Malaria entomology and vector control. Geneva: World Health Organization; 2013. p. 192

39. O'Connor CT, Soepanto A. Illustrated key to female Anophelines of Indonesia. Jakarta: Directorate of Communicable Disease, Ministry of Health; 1979. p. $5-17$.

40. Zhang DX, Hewitt GM. Assessment of the universality and utility of a set of conserved mitochondrial COXI primers in insects. Insect Mol Biol. 1997;6:143-50.

41. Gascuel O, Gouy M, Lyon D. SeaView Version 4: a multiplatform graphical user interface for sequence alignment and phylogenetic tree building. Mol Biol Evol. 2010;27:221-4

42. Kumar S, Stecher G, Li M, Knyaz C, Tamura K. MEGA X: molecular evolutionary genetics analysis across computing platforms. Mol Biol Evol. 2018:35:1547-9.
43. Tamura K, Stecher G, Peterson D, Filipski A, Kumar S. MEGA6: molecular evolutionary genetics analysis version 6.0. Mol Biol Evol. 2013;30:2725-9.

44. Dusfour I, Blondeau J, Harbach RE, Vythilingham I, Baimai V, Trung HD, et al. Polymerase chain reaction identification of three members of the Anopheles sundaicus (Diptera: Culicidae) complex, malaria vectors in Southeast Asia. J Med Entomol. 2007:44:723-31.

45. Dusfour I, Linton Y, Cohuet A, Harbach RE, Baimai V, Trung HD, et al. Molecular evidence of speciation between island and continental populations of Anopheles (Cellia) sundaicus (Diptera: Culicidae), a principal malaria vector taxon in Southeast Asia. J Med Entomol. 2004;41:287-95.

46. Sallum MAM, Peyton EL, Wilkerson RC. Six new species of the Anopheles leucosphyrus group, reinterpretation of An. elegans and vector implications. Med Vet Entomol. 2005;19:158-99.

47. Coleman AW. ITS2 is a double-edged tool for eukaryote evolutionary comparisons. Trends Genet. 2003;19:370-5.

48. Álvarez I, Wendel JF. Ribosomal ITS sequences and plant phylogenetic inference. Mol Phylogenet Evol. 2003;29:417-34.

49. Rampersad SN. ITS1,5.8S and ITS2 secondary structure modelling for intra-specific differentiation among species of the Colletotrichum gloeosporioides sensu lato species complex. Springerplus. 2014;3:684.

50. Qin Y, Li M, Cao Y, Gao Y, Zhang W. Molecular thresholds of ITS2 and their implications for molecular evolution and species identification in seed plants. Sci Rep. 2017;7:17316.

51. Beebe NW, Ellis JT, Cooper RD, Saul A. DNA sequence analysis of the ribosomal DNA ITS2 region for the Anopheles punctulatus group of mosquitoes. Insect Mol Biol. 1999;8:381-90.

52. Torres EP, Foley DH, Saul A. Ribosomal DNA sequence markers differentiate two species of the Anopheles maculatus (Diptera: Culicidae) complex in the Philippines. J Med Entomol. 2000;37:933-7.

53. Paskewitz SM, Wesson DM, Collins FH. The internal transcribed spacers of ribosomal DNA of five members of the Anopheles gambiae species complex. Insect Mol Biol. 1993;2:247-57.

54. Xu JN, Qu FY. Ribosomal DNA difference between species A and D of the Anopheles dirus complex of mosquitoes from China. Med Vet Entomol. 1997;11:134-8.

55. Clarkson CS, Weetman D, Essandoh J, Yawson AE, Maslen G, Manske $M$, et al. Adaptive introgression between Anopheles sibling species eliminates a major genomic island but not reproductive isolation. Nat Commun. 2014;5:4248.

56. Besansky NJ, Powello JR, Cacconet A, Hamm DM, Scott JA, Collins FH. Molecular phylogeny of the Anopheles gambiae complex suggests genetic introgression between principal malaria vectors. Proc Natl Acad Sci USA. 1994;91:6885-8.

57. Fontaine MC, Pease JB, Steele A, Waterhouse RM, Neafsey DE, Sharakhov IV, et al. Extensive introgression in a malaria vector species complex revealed by phylogenomics. Science. 2016;347:1258524.

58. Morgan K, Linton Y, Somboon P, Saikia P, Dev V, Duong S, Walton C. Inter-specific gene flow dynamics during the Pleistocene-dated speciation of forest-dependent mosquitoes in Southeast Asia. Mol Ecol. 2010;19:2269-85

59. Chen B, Pedro PM, Harbach RE, Somboon P, Walton C, Butlin RK. Mitochondrial DNA variation in the malaria vector Anopheles minimus across China, Thailand and Vietnam: evolutionary hypothesis, population structure and population history. Heredity. 2011;106:241-52.

60. Zarowiecki M, Loaiza JR, Conn J. Towards a new role for vector systematics in parasite control. Parasitology. 2012;138:1723-9.

61. Voris HK. Maps of Pleistocene sea levels in Southeast Asia: shorelines, river systems and time durations. J Biogeogr. 2000;27:1153-67.

62. Hanebuth T, Stattegger K, Grotes PM. Rapid flooding of the Sunda shelf: a late-glacial sea-level record. Science. 2000;288:1033-5.

63. Brandon-Jones D. Presbytis fredericae (Sody, 1930), an endangered colobine species endemic to Central Java, Indonesia. Primate Conserv. 1996;16:68-70.

64. Gathorne-Hardy F, Syaukani D, Jones D. A regional perspective on the effects of human disturbance on the termites of Sundaland. Biodivers Conserv. 2002;11:1991-2006.

65. Gorog A, Sinaga M, Engstrom M. Vicariance or dispersal? historical biogeography of three Sunda shelf murine rodents (Maxomys surifer, Leopolamys sabanus and Maxomys whiteheadi). Biol J Linn Soc. 2004;81:91-109.

66. Morgan K, Somboon P, Walton C. Understanding Anopheles diversity in Southeast Asia and its applications for malaria control. In: Manguin S, 
editor. Anopheles mosquitoes : new insights into malaria vectors. London: IntechOpen; 2013. p. 327-55.

67. Bemmelen RWV. General geology of Indonesia and adjacent archipelagoesc. The geology of Indonesia, vol. IA. Hague: Government Printing Office; 1949. p. 1-709.

68. Soesilo R. The experimental responsiveness of Myz. rosii for malaria infections. Ned J Health Treat. 1928;68:725-31.

69. Lestari E, Sukowati S, Soekidjo, Wigati R. The malaria vector in the Menoreh hill area, Purworejo, Central Java. Media Health Res Dev. 2007:17:30-5.

70. Shinta S, Sukowati S. Some behavioral aspects of An. maculatus Theobald in Pituruh Purworejo District Central Java. J Ekol Kesehat. 2012;11:73-82.
71. Widyastuti U, Boewono DT, Widiarti, Supargiyono, Satoto TBT. Vectorial competency of Anopheles maculatus Theobald in Kokap sub-district, Kulon Progo. Media Health Res Dev. 2013;23:47-57.

\section{Publisher's Note}

Springer Nature remains neutral with regard to jurisdictional claims in published maps and institutional affiliations.
Ready to submit your research? Choose BMC and benefit from:

- fast, convenient online submission

- thorough peer review by experienced researchers in your field

- rapid publication on acceptance

- support for research data, including large and complex data types

- gold Open Access which fosters wider collaboration and increased citations

- maximum visibility for your research: over $100 \mathrm{M}$ website views per year

At BMC, research is always in progress.

Learn more biomedcentral.com/submissions 